\title{
MAYFLIES (INSECTA: EPHEMEROPTERA) OF CONSERVATION CONCERN IN MONTANA: STATUS UPDATES AND MANAGEMENT NEEDS
}

\author{
David M. Stagliano 1,2
}

\begin{abstract}
Montana is home to 133 documented species of mayflies (Insecta: Ephemeroptera) from 55 genera in 16 families. This study reports on the conservation status, critical habitat, and management needs of 7 mayfly species that are currently listed as Montana species of concern (SOC) and 2 species that are currently listed as potential species of concern (PSOC). Six (67\%) of these listed mayflies (Anepeorus rusticus, Analetris eximia, Homoeoneuria alleni, Lachlania saskatchewanensis, Macdunnoa nipawinia, and Raptoheptagenia cruentata) are associated with the sand and gravel benthic habitats of large prairie rivers. Two other mayfly species, Caurinella idahoensis (SOC) and Caudatella edmundsi (PSOC), are associated with small, densely forested streams of the Northern Rocky Mountain Refugium area of the Montana and Idaho border. Distributional data provided for Ametropus neavei (Ametropodidae) and Pseudiron centralis (Pseudironidae) may warrant these species being added to the SOC list. Records of the newest mayfly species recorded in Montana, Cercobrachys cree, are also discussed.
\end{abstract}

Resumen.-Montana es el hogar de 133 especies documentadas de efímeras (Insecta: Ephemeroptera) de 55 géneros en 16 familias. Este estudio informa sobre las situación y las necesidades de gestión de la conservación de siete especies efímera que figuran actualmente como especies de interés Montana (SOC) y dos figuran como especies potenciales de preocupación (ESCP). Seis (67\%) de estas efímeras enumerados (Anepeorus rusticus, Analetris eximia, Homoeoneuria alleni, Lachlania saskatchewanensis, Macdunnoa nipawinia y Raptoheptagenia cruentata) están asociados con la arena y la grava bentónicos hábitats de grandes ríos de la pradera. Otras dos especies de moscas de mayo, Caurinella idahoensis (SOC) y Caudatella edmundsi (PSOC), están asociados con pequeños arroyos, densamente boscosas de la zona norte de las Montañas Rocosas Refugium de la frontera de Montana y Idaho. Datos de distribución previstas Ametropus neavei (Ametropodidae) y Pseudiron centralis (Pseudironidae) pueden justificar estas especies que se agregan a la lista SOC. Los registros de las especies de moscas de mayo más recientes registrados en Montana, Cercobrachys cree, se discuten.

Montana is home to 133 documented species of mayflies (Insecta: Ephemeroptera) from 55 genera in 16 families (McCafferty et al. 2012). This species richness is low considering the size of the state, the diversity of ecoregions, and the degree of topographic relief (Woods et al. 2002). Other states with much less area and altitudinal variation (North Carolina, South Carolina, and Virginia) are reported to have 170 to over 200 mayfly species (McCafferty and Meyer 2008, McCafferty et al. 2010). However, Montana does surpass its Canadian provincial neighbors, Alberta and Saskatchewan, in mayfly richness by 11 and 22 species, respectively (Webb 2002, Webb et al. 2004, Webb and McCafferty 2004). Nine of Montana's mayfly species from 5 families are considered to be species of conservation concern (SOC) (7 spp.) or potential species of concern (PSOC) (2 spp.) based on their rarity, their population declines, or their environmental specificity within the state (MTNHP 2015, NatureServe 2015; Table 1). However, perceived species rarity, whether due to the lack of targeted surveys in suitable habitats or the lack of taxonomic resolution, has led to some invertebrate species being placed on Montana's species of concern list in the past and then being subsequently removed (e.g., Caenis youngi, Caudatella edmundsi, Stagnicola elrodi; MTNHP 2015). This process of delisting or listing additional species may continue as unique aquatic insect habitats are targeted and sampled more effectively (Newell and Baumann 2013). Additional mayfly SOC listings may also come with more comprehensive adult collections and DNA analyses (Meyer and McCafferty 2007, Webb et al. 2007, Webb et al. 2012), because some Montana mayflies in the Heptageniidae family (and others) are ranked as globally rare or uncommon (Cinygma dimicki G3, Cinygmula gartrelli

${ }^{1}$ Montana Natural Heritage Program, 1515 E. Sixth Ave., Box 201800, Helena, MT 59620-1800.

2Present address: Montana Biological Survey, 1901 Peosta Ave., Helena, MT 59601. E-mail: dstagliano88@gmail.com 


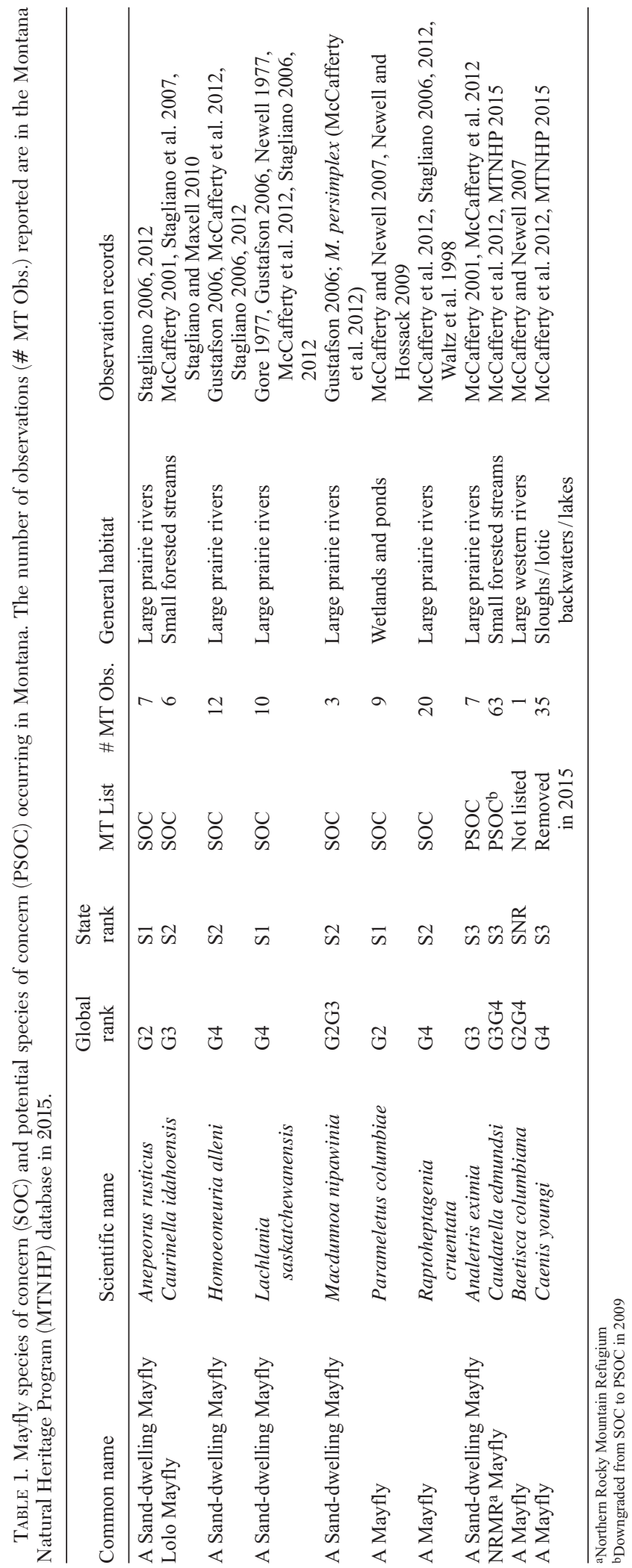




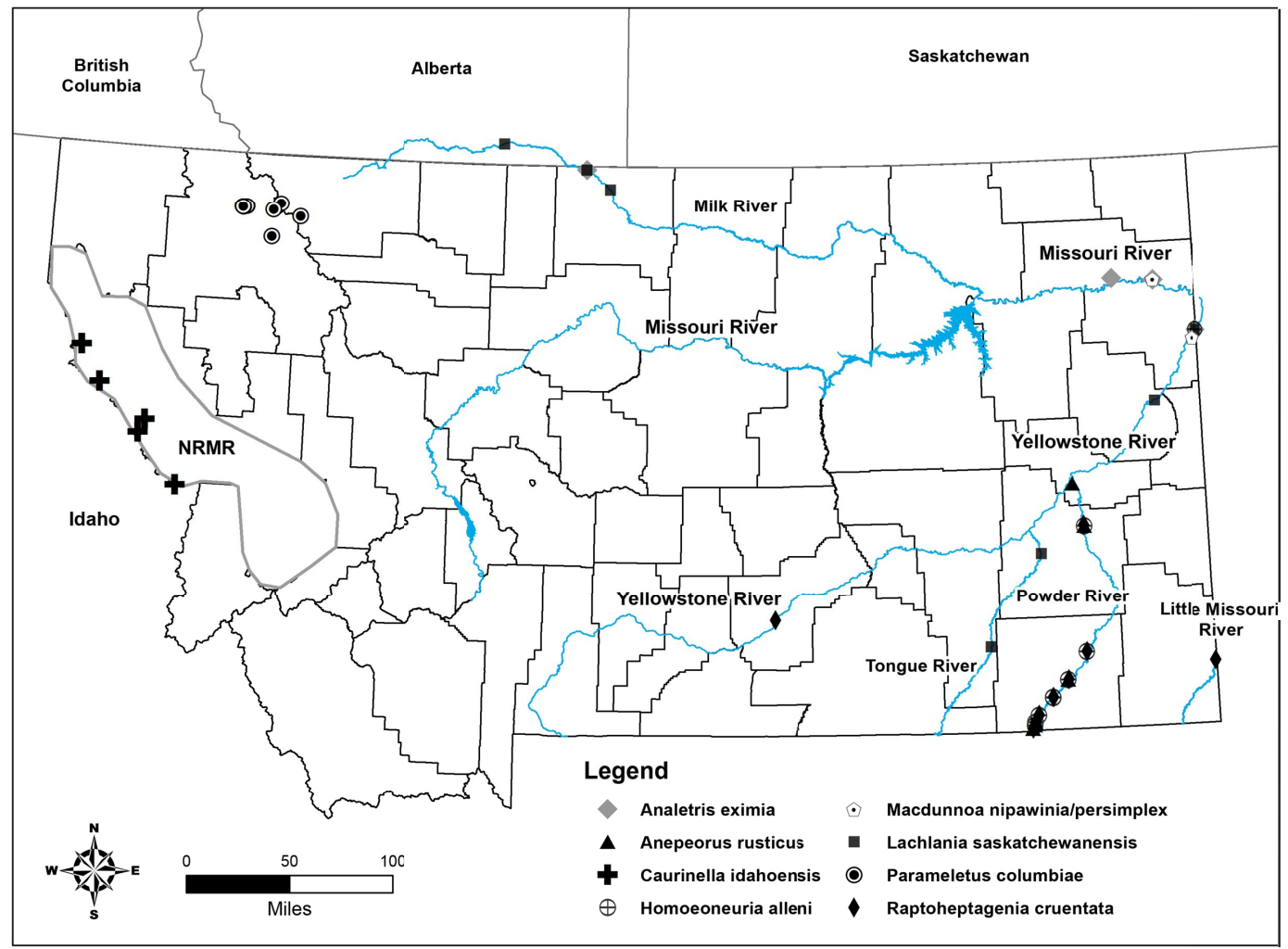

Fig. 1. Distributions of mayfly species of concern (SOC) in Montana. Eastern prairie rivers are labeled and the Northern Rocky Mountain Refugium (NRMR) is outlined in gray.

G2G3, and Heptagenia whitingi G2G3) but have not been placed on the SOC list because of taxonomic difficulties with identifying nymphs to species.

Six $(67 \%)$ of Montana's mayfly species of conservation concern (Anepeorus rusticus, Analetris eximia, Homoeoneuria alleni, Lachlania saskatchewanensis, Macdunnoa nipawinia, and Raptoheptagenia cruentata) are associated with the sand (i.e., psammophilous) and gravel benthic habitats of large prairie rivers in the eastern part of the state (Table 1, Fig. 1). In most cases, these psammophilous mayfly species are rare throughout their known range, but in other cases, they are endemic to a couple of western states or provinces (Lehmkuhl 1979, McCafferty et al. 2012). Only rarely are just their Montana populations vulnerable or declining (NatureServe 2015). In the Powder River basin of southeastern Montana and Wyoming, which has been undergoing coal bed natural gas (CBNG) production, I have reported short-term (within a decade) declines in the populations of 3 of these rare sand-dwelling mayflies (Stagliano 2012). It became apparent that Montana's rarest and most specialized mayflies were associated with sand-bottomed rivers. Subsequently, 5 of these species were added to the SOC list in 2006 (MTNHP 2015; Table 1).

Two other globally rare and uncommon mayfly species, Caurinella idahoensis (SOC) and Caudatella edmundsi (PSOC), are associated with small, forested streams of the Northern Rocky Mountain Refugium area of the Montana-Idaho border (Stagliano et al. 2007, Newell et al. 2008; Fig. 1). This region was spared massive glaciation during the Pleistocene Epoch and served as an island refuge, which led to disjunct distributions and speciation events for both terrestrial and aquatic taxa (Fend and Gustafson 2001, Leonard et al. 2003, Stark and Gustafson 2004, Hendricks 2003, Stagliano et al. 2007). 


\section{Methods}

Mayfly occurrence data presented in this study were compiled from MTNHP's aquatic zoologist field collections, personal communications with D. Gustafson (Montana State University, retired), and literature reviews undertaken to evaluate SOC macroinvertebrate distributions during project agreements with the Bureau of Land Management (BLM), the U.S. Forest Service (USFS) Northern Region, and the Idaho Department of Fish and Game during preparation of their Comprehensive Fish and Wildlife Conservation Strategy (CFWCS; Stagliano et al. 2007, Stagliano and Maxell 2010). Ephemeroptera species nomenclature followed taxonomic classifications according to Mayfly Central (2015). All data in the MTNHP database are publicly available and have been integrated into the NatureServe databases to enable global ranking of species (NatureServe 2015). Each species' conservation status presented is based on the international NatureServe/Natural Heritage Program (NHP) ranking system, in which globally rare and imperiled species are ranked G1 (on a scale of G1 to G5) and state imperiled species are ranked S1 (S1 to S5); species unranked in the state are designated as SNR (Master et al. 2003, NatureServe 2015). In the majority of state SOC listings, a global rank status of G3 will trigger consideration for that species to be added to the list.

\section{Critical SOC Mayfly Habitats}

\section{Sand-bottomed Prairie Rivers}

Large, warm-water prairie rivers of eastern Montana (Fig. 1) contain shifting sand and gravel benthic habitats that tend to support benthic macroinvertebrates low in diversity but highly specialized in their behaviors (McCafferty et al. 1990). In general, these habitats have been undersampled by the state's water quality monitoring crews because of the difficulties associated with sampling unstable, shifting sand bottoms (Williams and Mundie 1978). Montana’s state-sponsored macroinvertebrate monitoring protocols have focused on sampling the richest targeted habitats in rivers (e.g., cobble riffles; MTDEQ 2012); therefore, historical data on the macroinvertebrate communities of these sand habitats are limited, mostly qualitative, and sourced from unpublished or gray literature sources (Newell 1977,
Rehwinkel 1978, Gustafson 2006, Stagliano 2006, 2012). However, recent updates to staterecords lists from archived or more recently collected specimens have provided published records for many of Montana's SOC species (McCafferty et al. 2012). To further complicate reliable collection records, these sand-dwelling mayflies are fast swimmers that often evade typical benthic sampling methods (Lehmkuhl 1979; D.L. Gustafson, Montana State University, personal communication, April 2006). I and others have swept rectangular dip nets larger than normally used for standardized bioassessment protocols ( $>40 \mathrm{~cm}$ wide) over long stretches of sandbar habitat to improve capture efficiency of these unique species (D.L. Gustafson, Montana State University, personal communication, April 2006; Newell 1977, Stagliano 2012). We found that populations of psammophilous macroinvertebrates have been in decline for decades due to habitat alteration and loss from dam effects and also due to the channelization of river corridors (Lehmkuhl 1979, McCafferty et al. 1990).

Management NEEDS.-For the conservation requirements of these species to be addressed properly, significant time and effort will be needed to determine actual distributions and quantitative population estimates using specialized equipment and techniques. Management decisions regarding flow operations below the major dams on the Milk, Marias, and Missouri Rivers of Montana will need to be addressed if the habitat is to be restored or at least not progressively lost. Managing flows below Fort Peck Dam to benefit the critical sandbar habitat designated for the USFWS endangered Piping Plover (Charadrius melodus) (USFWS 2003) or to trigger spawning in the Pallid sturgeon (Scaphirhynchus albus) (USFWS 2014) may also benefit the benthic habitats preferred by these mayflies. Until a comprehensive statewide or regional-scale assessment can be implemented and new distributional data collected, the following 6 species should be considered as Montana's mayflies of highest conservation concern (Table 1).

Analetris eximia (Edmunds and Koss 1972) (Acanthametropodidae)

NatureServe Conservation Status: G3 S3 PSOC

This species is a member of one of the least collected and least known families of mayflies in North America (Lehmkuhl 1976). In the 
Saskatchewan River, nymphs were not collected in the main thalweg current but in the sandy, slow eddies behind obstructions, such as boulders or concrete boat launch ramps (Lehmkuhl 1976). Montana currently has 7 occurrence records in the MTNHP database from the lower Missouri and Yellowstone Rivers and additional records in the Milk River (McCafferty 2001, McCafferty et al. 2012; Fig. 1).

\section{Anepeorus rusticus McDunnough 1925} (Heptageniidae)

NatureServe Conservation Status: G2 S1 SOC

This species has a fickle taxonomic history, was once known as Acanthomola pubescens, and was also thought to be the larvae of Raptoheptagenia (Whiting and Lehmkuhl 1987). Montana currently has 7 occurrence records in the NHP database, all from the Powder River of southeastern Montana (Fig. 1). I have recently reported declining numbers of this predacious, sand-dwelling mayfly in Montana causally linked to coal bed natural gas production in the Powder River basin upstream in Wyoming (Stagliano 2012).

\section{Homoeoneuria alleni Pescador and Peters 1980 (Oligoneuriidae)}

NatureServe Conservation Status: G4 S2 SOC

Until recently, this species' distribution in Montana was known from only one published record in the Powder River (McCafferty 2001). Since 2005, twelve records have been reported from the Yellowstone and Powder Rivers of Montana (Gustafson 2006, Stagliano 2006, 2012). Stagliano (2012) reported on the shortterm population declines of this species in the Powder River while monitoring aquatic communities between 2005 and 2012, the height of Wyoming's coal bed natural gas production.

\section{Lachlania saskatchewanensis Ide 1941 (Oligoneuriidae) \\ NatureServe Conservation Status: G4 S1 SOC}

This species was, until recently, known only from Saskatchewan (Lehmkuhl 1979), where it was found in the South Saskatchewan River. Newell (1977) and Gore (1977) reported the species L. 'powelli', which has been synonymized with Lachlania saskatchewanensis, in Montana at the Intake site on the lower Yellowstone and 2 sites on the Tongue River, respectively (Fig. 1). Gustafson (2006) reported this species at sites on the Milk, Yellowstone, and Powder Rivers between 2002 and 2005. I have recollected this species at the known site on the Milk River but have not collected this species again in the Powder River basin (Stagliano 2012). Montana currently has 10 occurrence records in the MTNHP database from the Milk, lower Yellowstone, Powder, and Tongue Rivers (McCafferty et al. 2012; Fig. 1).

\section{Macdunnoa nipawinia Lehmkuhl 1979 (Heptageniidae) \\ NatureServe Conservation Status: G2G3 S2 SOC}

This species was, until recently, known only from Saskatchewan (Lehmkuhl 1979), where it was found on gravel beds and submerged woody debris in the South Saskatchewan River. This species was reported as present in Montana, with 2 records from one site on the lower Yellowstone River (Gustafson 2006). A preliminary global ranking has been given to this species (NatureServe 2015), and we placed it on the state's SOC list (MTNHP 2015). Another globally uncommon (G4), but more widespread species, Macdunnoa persimplex, has been reported from the lower Missouri River in Montana (McCafferty et al. 2012) (Fig. 1). We are currently trying to resolve whether this new species record is a substantial eastward expansion into the upper Missouri River Basin and whether Montana has both species or just one.

Raptoheptagenia cruentata (Walsh, 1863) (Heptageniidae)

NatureServe Conservation Status: G4 S2 SOC

This species' global range includes Illinois, Indiana, Nebraska, Kansas, Ohio, Tennessee, Manitoba, and Saskatchewan (Whiting and Lehmkuhl 1987). More recently $R$. cruentata has been found in large rivers in western North Dakota (Guenther and McCafferty 2005), eastern Wyoming, and Montana (McCafferty et al. 2012). Although considered uncommon in large rivers in the Midwest, this species is abundant and often collected in shallow riffles in small to medium prairie rivers (Guenther and McCafferty 2005). Montana has 20 occurrence records in the MTNHP database from the Powder, Yellowstone, and Little Missouri Rivers (Fig. 1). We have documented significant declines of this species in a 40-km reach near the Wyoming border while monitoring 
the Powder River during the period of CBNG growth in the early 2000s (Stagliano 2012). While not technically a psammophilous mayfly species, this species has been collected most frequently in the riffles (cobbles with gravels) within these large prairie rivers.

\section{Unranked Sand-dwelling Mayflies}

Currently unranked in Montana, the following 3 species co-occur with previously discussed SOC psammophilous mayflies in the large prairie rivers of Montana; therefore, the loss of suitable river habitat, the continuation of long-term population declines, and the expanding threats of flow regime shifts due to climate change in the state may warrant listing them on the SOC list or at least the PSOC list in the future. Until a statewide, largescale sampling effort can be employed to determine more accurate baseline population estimates of these sand-dwelling mayflies, we cannot be confident in determining shortterm population trends needed for the species conservation ranking process.

\section{Ametropus neavei McDunnough 1928 (Ametropodidae) \\ NatureServe Conservation Status: G4 SNR}

This species has recently been synonymized into Ametropus fragilis Albarda, 1878 (Mayfly Central 2015), but this change has not been updated in the NatureServe database. The eastern range limit of this species is North Dakota, Manitoba, and Saskatchewan (Guenther and McCafferty 2005). Newell (1977) reported low numbers of this genus, which we assigned to this species, at one site on the lower Yellowstone River. Montana currently has 11 occurrence records in the NHP database from the Milk, lower Yellowstone, and Powder Rivers (McCafferty et al. 2012).

\section{Cercobrachys cree Sun, Webb, and McCafferty 2002 (Caenidae) \\ NatureServe Conservation Status: G4 SNR}

This species is one of the most recently described mayfly species occurring in the large prairie rivers of northern and eastern Montana (Milk and Powder Rivers) (Sun et al. 2002). Larvae of this species were collected from the periphery of shifting sand bars and from slower-current nearshore areas. North Dakota, South Dakota, and Saskatchewan represent eastern range limits for this species
(Guenther and McCafferty 2005, Sun and McCafferty 2008). Montana has 14 occurrence records from the Milk, Missouri, and Powder Rivers (Fig. 1).

\section{Pseudiron centralis McDunnough, 1931} (Pseudironidae)

\section{NatureServe Conservation Status: G5 SNR}

Montana has only one occurrence record of the White sand-river mayfly, Pseudiron centralis, in the NHP database from the Milk River near the Canadian Border (McCafferty 2009). In this reach, the river still maintains a natural flow regime with large shifting sand bars. Nymphs burrow into clean (free of silt), shifting (not compacted) sand in the fastest portions of the rivers (Williams and Mundie 1978, Deyrup and Franz 1994). Since this species has a wider distribution across eastern and central North America than other sanddwelling mayflies occurring in Montana, it may likely be the only mayfly considered for the state SOC list that is ranked globally common (G5). Currently, we do not have enough information to rank this species.

\section{Northern Rocky Mountain Refugium (NRMR)}

Recently surveyed forested headwater streams of western Montana watersheds have yielded significant discoveries of species of conservation concern (SOC), range extensions, endemic genera, disjunct populations, and newly described species (Frest and Johannes 1995, Fend and Gustafson 2001, Hendricks 2003, Leonard et al. 2003, Stark and Gustafson 2004, Stagliano et al. 2007). This hotspot of endemism straddling the Idaho border has been referred to as the Northern Rocky Mountain Refugium (NRMR) (Johnston and Steele 1978, Stark and Gustafson 2004, Stagliano et al. 2007; Fig. 1). The NRMR area is bounded by Idaho's Clearwater National Forest and the western portion of the Lolo National Forest in Montana; a portion of the area in Idaho has been called the Clearwater Refugium (Daubenmire 1975). Numerous species are documented regional endemics of the NRMR known only to occur in western Montana and Idaho, including 2 mayfly species (Jacobus and McCafferty 2004, Hogue and Hawkins 2008).

Management neEds.-Protection of some NRMR forested landscapes as Research Natural Areas north of Lolo Pass that drain streams along the stateline divide into Montana and 
Idaho may be warranted as a management decision for the USFS Northern Region (Fig. 1). The proposed Great Burn Wilderness in the Lolo National Forest would provide some additional protection to these NRMR species.

\section{Caurinella idahoensis Allen 1984 (Ephemerellidae) Lolo Mayfly}

NatureServe Conservation Status: G3 S2 SOC

This mayfly continues to be a rarely collected SOC in western Montana, and it has been found only on USFS-owned lands close to the Idaho border. Prior to 2006, it was known from only 6 recorded occurrences in Idaho and Montana. MTNHP surveys added 4 new stream occurrence records under USFS collection projects in 2006 for a total of 6 occurrence records in Montana (Stagliano et al. 2007, Stagliano and Maxell 2010; Fig. 1). It has been reported from 3 streams within the Northern Rocky Mountain Refugium area of Mineral and Missoula Counties and from Lolo Pass north to Lookout Pass in Mineral County, with an additional site at Prospect Creek in Sanders County (Stagliano et al. 2007; Fig. 1). Originally, this species was collected from West Fork Lolo Creek, a perennial, secondorder stream near Lolo Pass, Missoula County (Jacobus and McCafferty 2004). The habitat description of the species collections from Bridge Creek, Idaho, indicate occurrence on cobble surfaces in a clear, cold $\left(10{ }^{\circ} \mathrm{C}\right.$ summer temperature), moderately swift current with a preference toward macrocolonies of the bluegreen alga Nostoc (Jacobus and McCafferty 2004). This species is also known from the North Fork Clearwater River in Idaho and closely adjacent areas of the Clark Fork River Basin, Montana (Stark and Gustafson 2004). In Idaho, it has been reported from scattered localities in the central mountainous part of the state: 12 locations reported in Valley, Lemhi, Idaho, and Clearwater Counties (Stagliano et al. 2007) and 7 sites reported by the Idaho DEQ and in Brushy Creek as reported by Jacobus and McCafferty (2004).

Caudatella edmundsi (Allen 1959) (Ephemerellidae)

Rocky Mountain Refugium Mayfly

Nature Serve Conservation Status: G3G4 S3 PSOC

Prior to 2001, this species was not recorded from Montana, and in 2006, MTNHP added it to the SOC list based on a limited number of occurrence records (MTNHP 2015). Recent targeted surveys in the USFS regions of western Montana and Idaho have greatly increased the known distribution (Stagliano et al. 2007, Stagliano and Maxell 2010). It was determined that this species is fairly wide-ranging in the western portion of the state with 63 occurrences, so it was dropped from the SOC list but retained on the PSOC list because of its habitat specialization (MTNHP 2015). Rangewide this species is known from the coastal ranges of western Oregon and California, as well as from mountainous regions of Washington, Idaho, and western Montana (Jacobus et al. 2006, Meyer and McCafferty 2007, Hogue and Hawkins 2008). The larvae appear to be restricted to the aquatic moss Fontinalis (Fontinalaceae). Hundreds of individuals have been observed crawling in mats of this moss (George Edmunds personal communication), and larvae are only collected from samples targeting this habitat (Hawkins 1985).

\section{Slow-Moving Vegetated Streams, Sloughs, or Wetlands}

Two mayflies, Baetisca columbiana (Baetiscidae) and Caenis youngi (Caenidae) (Table 1), along with other Montana species from these families, inhabit the depositional margins of slow-flowing rivers with aquatic vegetation. All species within the family Siphlonuridae, of which SOC Parameletus columbiae belongs, inhabit lentic environments (e.g., wetlands with aquatic macrophytes) or riverine backwater side-channels in western Montana.

\section{Baetisca columbiana Edmunds 1960 (Baetiscidae) \\ NatureServe Conservation Status: G2G4 SNR}

Montana has only one occurrence record in the MTNHP database from the Flathead River, below Seepay Creek, approximately 3 miles downstream of Perma (McCafferty and Newell 2007). This species is restricted to western North America (Alberta, Idaho, Saskatchewan, Washington, and now Montana).

\section{Caenis youngi Roemhild 1984 (Caenidae) \\ NatureServe Conservation Status: G4 S3 (Removed from SOC list in 2015)}

This species initially had few occurrence records and a perceived limited distribution in Montana, and it was added to the SOC list as 
an S2 in 1987 (MTNHP 2015). Locations and habitat presented in the original species description indicated that this species was limited to slow-moving waters in the Yellowstone Park area of Montana (Roemhild 1984). However, recent surveys across other ecoregions and habitats of the state (Stagliano 2012, Newell and Baumann 2013) have increased the number of site occurrences to 35 , and the species is now considered to have a statewide distribution and to be common in the state (McCafferty et al. 2012).

Parameletus columbiae McDunnough, 1938 (Siphlonuridae)

NatureServe Conservation Status: G2 S1 SOC

This large-bodied, swimming mayfly species is listed as a species of concern in several western states and British Columbia (NatureServe 2015). The habitat and biology of this species was documented from a high-mountain, wetland area in Utah (Edmunds 1957), where, ironically, this species appears to be extirpated (NatureServe 2015). This species hatches during snowmelt from dormant eggs laid the previous summer, and it has a brief nymphal period (Edmunds 1957). Occurrence records exist for Idaho, and historical records exist for British Columbia and Wyoming. However, recent intensive surveys have reported no new specimens (Stagliano 2007). The imperiled (S1) SOC ranking status appears warranted for Montana at this time, because this species was only recently reported in 2008 when it was collected from 7 wetlands in Glacier National Park (NP), Montana (Newell and Hossack 2009; Fig. 1). Five of the P. columbiae collection sites sampled in mid-June were isolated, temporary marshes near the McGee Meadows area. Two sites were on the east side of Glacier NP, where mature nymphs were captured on 7 July and 26 July 2008. Parameletus columbiae has been collected previously from 2 locations in Glacier NP: an adult collected near Gunsight Pass on 19 July 1997 and a nymph collected from floodplain ponds along the Middle Fork of the Flathead River on 13 June 2002 (McCafferty and Newell 2007; Fig. 1).

\section{Discussion}

We have only begun to scratch the surface in evaluating the conservation status of aquatic insects in Montana. Only 11\% (14 spp.) of the state's mayflies have a state rank; 13 of the 119 unranked species (SNR) have global ranks of G2, G3 or G2G4, which may qualify them as species of concern. There are also unique species such as Pseudiron centralis, whose populations are secure globally (G5) but appear to be very restricted in Montana. Limited collections and distributional data provided for the unranked mayflies Ametropus neavei (Ametropodidae) and Pseudiron centralis (Pseudironidae) may warrant their addition to the SOC list despite more targeted surveys of sand habitat. One of Montana's SOC mayfly species, Anepeorus rusticus, has experienced documented short-term (within a decade) population declines in the Powder River (Stagliano 2012) and has been recommended for federal protection across the border in Canada (Webb 2002).

Insects rarely attain the high-profile conservation status of the state's megafauna (i.e., mammals, other vertebrates; Wilson 1988, Samways 2005). For example, no insects were included in Montana's Comprehensive Fish and Wildlife Conservation Strategy (CFWCS) or the State Wildlife Action Plan (SWAP) (MTFWP 2015), despite 2 Glacier NP stoneflies having been petitioned for protection under the Endangered Species Act (USFWS 2011). Identifying the critical and declining habitats where a large percentage of the state's SOC aquatic insects occur is a key step for including them in landscape-scale conservation actions (coarse-filter). An alternative approach to addressing rare insect species is to "piggyback" them onto the conservation efforts for a charismatic "umbrella species," such as the pallid sturgeon or Piping Plover (Andelman and Fagen 2000, Roberge and Angelstam 2004). This method would encompass insect species sharing their critical habitats (large sand/gravelbottomed rivers). To protect the endemic mayflies and other invertebrate species inhabiting the Northern Rocky Mountain Refugium area, conservation efforts for the Idaho Giant Salamander (a vertebrate Montana SOC) may be used to safeguard small, steep, forested streams that serve as critical habitats for these invertebrates. This study further underscores the need to bolster sampling and monitoring in Montana's atypical aquatic habitats (i.e., nonsalmonid bearing streams and waterbodies; see Muhlfeld et al. 2011), because that is apparently where the highest rarity exists 
and the next potential endangered insect species may be inhabiting.

\section{ACKNOWLEDGMENTS}

An early draft of this manuscript was reviewed by Adam Petersen and Bryce Maxell. I thank them both for their helpful comments and direction. Additional editorial reviews provided by Luke Jacobus, David Lightfoot, and 2 anonymous reviewers have greatly improved this manuscript. Dan Gustafson (Montana State University, retired) was extremely helpful in 2005 and 2006 with sharing mayfly site occurrence data and collection techniques. Much of the field collection and record compilation reported in this manuscript was accomplished during Montana Natural Heritage Program cost-share agreements with the Bureau of Land Management (BLM) and the USFS Northern Region.

\section{Literature Cited}

Andelman, S.J., AND W.F. FaGen. 2000. Umbrellas and flagships: efficient conservation surrogates or expensive mistakes? Proceedings of the National Academy of Sciences 97:5954-5959.

Daubenmire, R. 1975. Floristic plant geography of eastern Washington and northern Idaho. Journal of Biogeography $2: 1-18$.

Deyrup, M., and R. Franz. 1994. Rare and endangered biota of Florida, Volume IV: Invertebrates. University Press of Florida, Gainesville, FL. 798 pp.

EDmunds, G.F., JR. 1957. The life history of Parameletus columbiae McDunnough (Ephemeroptera). Utah Academy Proceedings 34:25-26.

Fend, S.V., And D.L. Gustafson. 2001. A new Lumbriculid genus and species from North America (Clitellata, Lumbriculidae). Hydrobiologia 463:13-22.

Frest, T.J., AND E.J. Johannes. 1995. Interior Columbia Basin mollusk species of special concern. Final report to the Interior Columbia Basin Ecosystem Management Project, Walla Walla, WA. Contract \#43-0E00-4-9112. 274 pp. + appendixes.

GoRe, J. 1977. Reservoir manipulations and benthic macroinvertebrates in a prairie river. Hydrobiologia $55: 113-123$

Guenther, J.L., AND W.P. MCCafferty. 2005. Mayflies (Ephemeroptera) of the Great Plains. III: North Dakota. Transactions of the American Entomological Society 131:491-508.

Gustafson, D.L. 2006. Aquatic invertebrates of Montana Unpublished raw data. Montana State University entomology collection (MTEC). Bozeman, MT

Hawkins, C.P. 1985. Food habits of species of Ephemerellidae (Insects: Ephemeroptera) in streams of Oregon. American Midland Naturalist 113:343-352.

Hendricks, P.D. 2003. Status and conservation management of terrestrial mollusks of special concern in Montana. Report to Region I, U.S. Forest Service.
Montana Natural Heritage Program, Helena, MT. 67 pp. + appendixes.

Hogue, J.N., and C.P. Hawkins. 2008. Notes on the distribution of the mayfly Caudatella edmundsi (Allen, 1959) (Ephemeroptera: Ephemerellidae). Pan-Pacific Entomologist 84:150-154.

Jacobus, L.M., and W.P. MCCafferty. 2004. Contribution to the morphology and descriptive biology of Caurinella idahoensis (Ephemeroptera: Ephemerellidae). Western North American Naturalist 64: 101-108.

Jacobus, L.M., R.L. Newell, and W.P. McCafferty. 2006. First adult and egg descriptions of Caudatella edmundsi (Ephemeroptera: Ephemerellidae) from Montana (U.S.A.), with habitat observations. Entomological News 117:175-180.

Johnston, F.D., AND R. STEELE. 1978. New plant records for the Idaho Pacific Coastal Refugia. Northwest Science 52:205-211.

LeHMkUhl, D.M. 1976. Additions to the taxonomy, zoogeography and biology of Analetris eximia (Acanthametropodidae: Siphlonuridae: Ephemeroptera). Canadian Entomologist 108:199-207.

LehmкuHL, D.M. 1979. A new genus and species of Heptageniidae (Ephemeroptera) from western Canada. Canadian Entomologist 111:859-862.

Leonard, W.P., L. Chichester, J. Baugh, and T. Wilke. 2003. Kootenaia burkei, a new genus and species of slug from northern Idaho, United States (Gastropoda: Pulmonata: Arionidae). Zootaxa 355:1-16.

Master, L.L., L.E. Morse, A.S. Weakley, G.A. HammerSON, AND D. Faber-Langendoen. 2003. NatureServe Conservation Status Assessment Criteria. NatureServe, Arlington, VA.

Mayfly Central. 2015. Mayfly Central: species list-North America [online]. W.P. McCafferty, founder; L.M. Jacobus, steward. Purdue University Department of Entomology, West Lafayette, IN; [accessed 15 February 2015]. http://www.entm.purdue.edu/mayfly/ na-species-list.php.

MCCAFFERTY, W.P. 2001. Notes on distribution and orthography associated with some poorly known North American mayflies (Ephemeroptera). Entomological News 112:119-120.

MCCAFFERTY, W.P. 2009. New state and provincial North American records for 100 Ephemeroptera species. Transactions of the American Entomological Society 135:353-368.

MCCAFFERTY, W.P., D.R. Lenat, L.M. Jacobus, and M.D. MEYER. 2010. The mayflies (Ephemeroptera) of the southeastern US. Transactions of the American Entomological Society 136:221-233.

McCafferty, W.P., and M.D. Meyer. 2008. South Carolina mayflies (Ephemeroptera). Transactions of the American Entomological Society 134:283-335.

McCafferty, W.P., and R.L. NewELL. 2007. Insecta, Ephemeroptera: range extensions and new state records from far western Montana, U.S.A. Check List 3:260-266.

McCafferty, W.P., R.P. RandolPh, and L.M. Jacobus. 2012. Mayflies of the Intermountain West. Memoirs of the American Entomological Institute 85:1-317.

McCafferty W.P., B.P. Stark, and A.P. Provonsha. 1990. Ephemeroptera, Plecoptera and Odonata. Pages 43-58 in M. Kosztarab and C. Schaefer, editors, Systematics of the North American insects and arachnids: status and needs. Virginia Agricultural 
Experiment Station Information Series Number 90-1, Virginia Polytechnic Institute and State University, Blacksburg, VA.

Meyer, M.D., and W.P. MCCafferty. 2007. Mayflies (Ephemeroptera) of the far western United States. Part I: Washington. Transactions of the American Entomological Society 133:21-63.

[MTDEQ] Montana Department of Environmental QUALITY. 2012. Sample collection, sorting, and taxonomic identification of benthic macroinvertebrates: standard operating procedure. WQPBWQM-012, Montana Department of Environmental Quality, Helena, MT

[MTFWP] Montana Fish, Wildlife and Parks. 2015. Montana's State Wildlife Action Plan. 2015. Montana Fish, Wildlife and Parks, Helena, MT. 441 pp.

[MTnhP] Montana Natural Heritage Program. 2015. Montana Natural Heritage - SOC Report [online]. Helena, MT. http://mtnhp.org/SpeciesOfConcern

Muhlfeld, C.C., J.J. Giersch, F.R. Hauer, G.T. Pederson, G. Luikart, D.P. Peterson, C.C. Downs, and D.B. FAGRE. 2011. Climate change links fate of glaciers and an endemic alpine invertebrate. Climatic Change 106:337-345.

NatureServe. 2015. NatureServe Explorer: an online encyclopedia of life [web application]. Version 7.0. NatureServe, Arlington, VA; [accessed 15 February 2015]. http://www.natureserve.org/explorer

NewelL, R.L. 1977. Aquatic invertebrates of the Yellowstone River Basin, Montana. Montana Department of Natural Resources and Conservation Technical Report No. 5, Yellowstone Impact Study. 109 pp.

Newell, R.L., and R.W. Baumann 2013. Studies on distribution and diversity of nearshore Ephemeroptera and Plecoptera in selected Lakes of Glacier National Park, Montana. Western North American Naturalist 73:230-236.

Newell, R.L., R.W. Baumann, and J.A. Stanford. 2008. Stoneflies of Glacier National Park and Flathead River basin, Montana. Pages 173-186 in F.R. Hauer, J.A. Stanford, and R.L. Newell, editors, International advances in the ecology, zoogeography and systematics of mayflies and stoneflies. Entomology, Vol. 128. University of California Press, Berkeley, CA. 412 pp.

Newell, R.L., AND B.R. Hossack. 2009. Large, wetlandassociated mayflies (Ephemeroptera) of Glacier National Park, Montana. Western North American Naturalist 69:335-342.

Rehwinkel, B. 1978. Powder River aquatic ecology project. Report to Utah International, Inc. Salt Lake City, UT. 42 pp.

Roberge, J.M., and P. Angelstam. 2004. Usefulness of the umbrella species concept as a conservation tool. Conservation Biology 18:76-85.

Roemhild, G. 1984. A new species of Caenis (Ephemeroptera: Caenidae) from Montana, U.S.A. Aquatic Insects 6:7-11.

SAmWAYS, M.J. 2005. Insect diversity conservation. University Press, Cambridge, United Kingdom.

Stagliano, D.M. 2006. Aquatic surveys and assessment within the Middle Powder River watershed. Report to the U.S. Bureau of Land Management (ESA 010009). Montana Natural Heritage Program, Helena, MT. 37 pp.

Stagliano, D.M. 2012. Aquatic surveys and re-assessment of sites within the Middle Powder River. Report for the U.S. Bureau of Land Management, Miles City Field Office and The Interagency BLM Aquatic Task Group. Montana Natural Heritage Program, Helena, MT. 19 pp.

Stagliano, D.M., And B.A. Maxell. 2010. Aquatic invertebrate species of concern: updated distributions, vital watersheds and predicted sites within USFS Northern Region Lands. Report prepared for USDA Forest Service, Northern Region, Missoula, MT. Montana Natural Heritage Program, Helena, MT. 30 pp. + appendixes.

Stagliano, D.M., G.M. Stephens, and W.R. Bosworth. 2007. Aquatic invertebrate species of concern on USFS Northern Region lands. Report prepared for USDA Forest Service, Northern Region, Missoula, MT. Montana Natural Heritage Program, Helena, MT, and Idaho Conservation Data Center, Boise, ID. Agreement number 05-CS-11015600-036. 95 pp. + appendixes.

Stark, B.P., and D.L. Gustafson 2004. New species and records of Soliperla Ricker, 1952 from western North America (Insecta: Plecoptera). Spixiana 27:97-105.

Sun, L., AND W.P. McCafferty. 2008. Insects: Ephemeroptera. Zootaxa 1801:1-239.

Sun, L., J.M. Webb, and W.P. McCafferty. 2002. Cercobrachys cree, a new species of Ephemeroptera (Caenidae) from western North America. Entomological News 113:80-86.

[USFWS] United States Fish and Wildlife Service. 2003. Online status paper on the Piping Plover in Montana. http://mountain-prairie.fws.gov/pipingplo ver/Piping_Plover_Q\&A_Sept5.htm

[USFWS] United States Fish and Wildifife Service. 2011. Meltwater lednian stonefly designated a candidate for Endangered Species protection. Invertebrates of the Mountain-Prairie Region [last updated 15 December 2011]. https://www.fws.gov/ mountain-prairie/es/species/invertebrates

[USFWS] United States Fish and Wildlife Service. 2014. Revised recovery plan for the pallid sturgeon (Scaphirhynchus albus). USFWS, Denver, CO.

Waltz, R.D., G.F. Edmunds JR., And G. Lester. 1998. New distributions for Raptoheptagenia cruentata and Ametropus neavei (Ephemeroptera: Heptageniidae, Ametropodidae). Entomological News 109: 213-214.

Weвb, J.M. 2002. The mayflies of Saskatchewan, Canada. Master's thesis, University of Saskatchewan, Saskatoon. 313 pp.

Webb, J.M., L.M. Jacobus, D.H. FunK, X. Zhou, B. KondratiefF, C.J. Geraci, R.E. DeWalt, D.J. Baird, B. Richard, and I. Phillips, ET AL. 2012. A DNA barcode library for North American Ephemeroptera: progress and prospects. PLOS ONE 7(5):e38063.

WebB, J.M., AND W.P. MCCAFFERTY. 2004. New records of mayflies (Ephemeroptera) from Alberta, Canada. Entomological News 114:230-232.

Webb, J.M., D.W. Parker, D.M. Lehmkuhl, and W.P. MCCAFFERTy. 2004. Additions and emendations to the mayfly fauna of Saskatchewan, Canada. Entomological News 115:213-218.

Webb, J.M., L. Sun, W.P. McCafferty, and V.R. Ferris. 2007. A new species and new synonym in Heptagenia Walsh (Ephemeroptera: Heptageniidae: Heptageniinae) based on molecular and morphological evidence. Journal of Insect Science 7: Article 63. 
Whiting, E.R., AND D.M. LehmkUhL. 1987. Acanthomola pubescens, a new genus and species of Heptageniidae (Ephemeroptera) from western Canada. Canadian Entomologist 119:409-417.

Williams, D.D., AND J.H. MundiE. 1978. Substrate size selection by stream invertebrates and influence of sand. Limnology and Oceanography 23:1030-1033.

Wilson, E.O. 1988. Biodiversity. National Academy Press, Washington, DC.
Woods, A.J., J.M. Omernik, J.A. Nesser, J. Shelden, J.A. Comstock, and S.H. Azevedo. 2002. Ecoregions of Montana. 2nd edition [color poster with map, descriptive text, summary tables, and photographs], map scale 1:1,500,000, U.S. Geological Survey, Reston, VA.

Received 21 January 2016 Accepted 27 September 2016 